\title{
NITROGEN FERTILIZATION AND SOIL MANAGEMENT OF WINTER COMMON BEAN CROP
}

\author{
Matheus Gustavo da Silva ${ }^{1}$; Orivaldo $\operatorname{Arf}^{1 *}$; Marco Eustáquio de Sá ${ }^{1}$; Ricardo Antônio Ferreira \\ Rodrigues $^{2}$; Salatiér Buzetti ${ }^{2}$ \\ ${ }^{1}$ UNESP/FEIS - Depto. Fitotecnia, Tecnologia de Alimentos e Sócio-Economia, C.P. 31 - 15385-000 - Ilha Solteira, \\ SP - Brasil. \\ ${ }^{2}$ UNESP/FEIS - Depto. Fitossanidade, Engenharia Rural e Solos. \\ *Corresponding author <arf@agr.feis.unesp.br>
}

\begin{abstract}
The adoption of appropriate cultural management, which includes nitrogen fertilization and soil tillage system, is very important to increase the efficiency of plant in the utilization of available resource. This research work was conducted for three years aiming at evaluating the effect of sidedressing nitrogen application $\left(0,25,50,75\right.$, and $\left.100 \mathrm{~kg} \mathrm{ha}^{-1}\right)$ on winter bean crop under different systems of soil management (conventional, minimal, and no-tillage systems). The experimental design was a randomized block arranged in strips relative to tillage systems, with random distribution of nitrogen doses into each strip, with four replications. Grain yield was affected by nitrogen rates and significant increases were obtained with the application of 75 to $100 \mathrm{~kg} \mathrm{~N}^{-1}$. Soil management did not affect grain yield, although the "minimum system" provided better results in the two first years.
\end{abstract}

Key words: Phaseolus vulgaris L., moldboard plow, disk harrow, nitrogen rates, no-tillage

\section{MANEJO DO SOLO E ADUBAÇÃO NITROGENADA EM FEIJOEIRO DE INVERNO}

\begin{abstract}
RESUMO: A adoção de manejo cultural adequado, dentro do qual se insere a prática da adubação e do preparo do solo, é importante no sentido de aumentar a eficiência da planta na utilização dos recursos disponíveis. Este trabalho foi desenvolvido durante três anos, objetivando avaliar, no feijoeiro irrigado (Phaseolus vulgaris) "de inverno", o efeito da aplicação de doses de nitrogênio em cobertura $(0,25,50,75$ e $100 \mathrm{~kg} \mathrm{ha}^{-1}$ ), sob diferentes sistemas de preparo de solo (convencional, mínimo e direto). O delineamento estatístico utilizado foi em blocos casualisados dispostos em faixas para os sistemas de preparo do solo, com casualização dentro destes para as doses de nitrogênio, com quatro repetições. Foram avaliados: florescimento pleno, matéria seca de plantas, número de vagens e de grãos por planta, número de grãos por vagem, massa de 100 grãos, ciclo, rendimento de grãos e teor de nitrogênio nas plantas. $\mathrm{O}$ rendimento de grãos foi influenciado pelas doses de nitrogênio e incrementos significativos foram obtidos com a aplicação de 75 a $100 \mathrm{~kg} \mathrm{~N}^{-1}{ }^{-1}$. Os sistemas de preparo do solo não influenciaram no rendimento de grãos, embora o "cultivo mínimo" tenha se sobressaído nos dois primeiros anos.

Palavras-chave: Phaseolus vulgaris L., escarificador, grade, doses de nitrogênio, plantio direto
\end{abstract}

\section{INTRODUCTION}

Although the common bean plants have N-fixation ability by symbiosis with Rhizobium, they are recommended to be nitrogen fertilized, because $\mathrm{N}$-fixation does not provide enough $\mathrm{N}$ to supply enough $\mathrm{N}$ to meet requirement of this crop (Coelho et al., 1998). The recommended $\mathrm{N}$ rate for common beans in the Cerrado (savanna) region of the States of São Paulo, Minas Gerais, Paraná, Espírito Santo and Santa Catarina, varies from 30 to $60 \mathrm{~kg} \mathrm{ha}^{-1}$, based on grain yield response curves for $\mathrm{N}$, since there is no correlation between grain yield and soil-organic matter or soil-N (Moraes, 1988).

Maximal grain yield was obtained for irrigated common beans cultivated in the region of Ilha Solteira, with the application of $63 \mathrm{~kg} \mathrm{ha}^{-1}$ of sidedressed $\mathrm{N}$ (Arf et al., 1992). On the other hand, increases in grain yield and other bean yield components such as total dry matter, shoot-N concentrations and contents, were obtained during winter season, for $\mathrm{N}$-fertilization rates up to $90 \mathrm{~kg} \mathrm{ha}^{-1}$, in a field experiment in the State of Goiás, in a Typical Acrustox (Silveira \& Damasceno, 1993). The use of higher rates of $\mathrm{N}$ has provided higher bean grain yields (Araújo et al., 1994; Barbosa Filho \& Silva, 2000; Guerra et al., 2000). The application of $75 \mathrm{~kg} \mathrm{ha}^{-1}$ of $\mathrm{N}$ has resulted in $38 \%$ increase in productivity, applied either in the sowing row or sidedressed, and increased total winter crop yield in the West Region of State of São Paulo (Carvalho et al., 2001). 
Soil tillage is a management practice as important as fertilization in what concerns the conservation of soil chemical, physical and biological properties. Castro et al. (1986), studying soil tillage systems at Pindorama and Campinas, municipal districts of the State of São Paulo, concluded that soil tillage with moldboard-plow resulted in superior grain yields when compared to the conventional tillage systems (leveling-disk and diskplow). Even though traditional tillage systems have been considered adequate for the common bean crop it is necessary to clearly define which of the traditional methods is the most interesting and efficient one (Kluthcouski et al., 1988; Sampaio et al., 1989; Siqueira et al., 1993). Some of the soil tillage systems may not affect common bean yielding (Zaffaroni et al., 1991; Landers, 1995; Stone \& Moreira, 2000). However, the no-tillage system was reported to be superior to the conventional systems in some situations, resulting in higher productivities (Silva et al., 1996; Silveira et al., 1999; Stone \& Silveira, 1999). Despite the relevance of such results, the use of the disk harrow may provide higher productivities for winter-irrigated common beans cultivated at the Central Region of the State of Goiás (Silveira et al., 2001) in comparison to other tillage systems. The authors reported, in addition, a decrease in bean yielding when the no-tillage system was continuously used. The objective of this research was thus evaluating the effect of sidedressed nitrogen fertilization and soil tillage practices on winter irrigated common bean yielding.

\section{MATERIAL AND METHODS}

The experiment was carried out at the municipal district of Selvíria, State of Mato Grosso do Sul, Brazil $\left(51^{\circ} 22^{\prime} \mathrm{W}, 20^{\circ} 22^{\prime} \mathrm{S}\right.$; altitude $\left.335 \mathrm{~m}\right)$, during the winter period of 2000, 2001 and 2002. The soil was a Typic Acrustox (USDA, 1996). Average annual rainfall of 1370 $\mathrm{mm}$, average annual temperature of $23.5^{\circ} \mathrm{C}$ and average annual relative humidity of $70-80 \%$ characterizes the region climate. The soil chemical attributes were determined in soil samples from the $0-0.20 \mathrm{~m}$ layer before the experiment, according to Raij \& Quaggio (1983), and results were as follows: $\mathrm{pH}\left(0.01 \mathrm{~mol} \mathrm{~L}^{-1} \mathrm{CaCl}_{2}\right)=5.7$; $\mathrm{O} . \mathrm{M} .=22 \mathrm{~g} \mathrm{~cm}^{-3} ; \mathrm{K}, \mathrm{Ca}, \mathrm{Mg}, \mathrm{H}+\mathrm{Al}$ and $\mathrm{Al}=1.1 ; 31.0$; 9.0; 20.0 and $0.0 \mathrm{mmol}_{\mathrm{c}} \mathrm{dm}^{-3}$, respectively; and $\mathrm{V}=67 \%$.

The experimental design was a randomized block arranged in soil strips and the treatments consisted of five $\mathrm{N}$-rates and three soil-tillage systems. The sidedressing $\mathrm{N}$-rates applied were: $0,25,50,75$, and $100 \mathrm{~kg} \mathrm{ha}^{-1}$. The soil tillage systems consisted of (a) disk-plow + disk harrow = conventional; (b) moldboard-plow + disk harrow $=$ minimal tillage; and (c) no-tillage. This latter system was studied in a 5-year-no-tillage area previously cultivated with maize, Tractor cultivar, with $0.90 \mathrm{~m}$ row spacing. The maize crop sowing was in January, after adequate fertilization rate recommended by Raij \& Cantarella (1996). After maize harvesting, the no-tillage area was prepared for the common bean cropping. A basic fertilizer rate was applied in the sowing rows according to the soil analysis and recommendations of Ambrosano et al. (1996), which consisted of $250 \mathrm{~kg} \mathrm{ha}^{-1}$ of a 08-28-16 (N$\mathrm{P}_{2} \mathrm{O}_{5}-\mathrm{K}_{2} \mathrm{O}$ ) formula. The $\mathrm{N}$-rates were sidedressed in a unique application, using urea, three weeks after seedling emergence. The plots consisted of six, $6 \mathrm{~m}$-rows, experimental units were the four central, 5 m-rows. Experiments used the common bean 'IAC-Carioca-Eté' cultivar, sowed in the third week of May, using sowing machine adjusted to $12-13$ plants $\mathrm{m}^{-1}$ and $0.50 \mathrm{~m}$ row spacing (IAC, 1999). Weeds, mainly Bidens pilosa, Commelina benghalensis, Panicum maximum Jacq., Ipomea grandifolia (Dammer) O'Don and other gramineae, were controlled using fluazifop-p-butil + fomesafen herbicide mixture $(200+$ $250 \mathrm{~g}$ a.i. ha $^{-1}$ ). Pests, mainly Bemisia tabaci and Bemisia argentifolii, Diabrotica speciosa and other coleoptera, were controlled using the methamidophos $\left(300 \mathrm{~g}\right.$ a.i. $\left.\mathrm{ha}^{-1}\right)$ and thiametoxan $\left(250 \mathrm{~g}\right.$ a.i. $\left.\mathrm{ha}^{-1}\right)$. It was also applied mancozeb $\left(1600 \mathrm{~g}\right.$ a.i. ha $\left.{ }^{-1}\right)$, benomyl $\left(250 \mathrm{~g}\right.$ a.i. ha $\left.^{-1}\right)$ and oxycarboxin $\left(375 \mathrm{~g}\right.$ a.i. $\left.\mathrm{ha}^{-1}\right)$. Field irrigation was done using conventional, water-spraying system.

The following variables were evaluated: (1) number of days from seedling emergence to full-flowering (50\% of experimental unit plant flowering); (2) shoot dry matter yields at full-flowering: 10 plants were collected from the experimental unit, dried in a forced-air oven at $60-70^{\circ} \mathrm{C}$ until constant mass and weighed; (3) shoot nitrogen concentration at full-flowering: 10 plants were collected from the experimental unit, dried in a forced-air oven at $60-70^{\circ} \mathrm{C}$ during $72 \mathrm{~h}$, ground in a Willey-type grinder, followed $\mathrm{N}$ determination in plant samples, after sulfuric digestion according to Sarruge \& Hagg (1974); (4) yield components at harvest: 10 plants were collected from the experimental unit and evaluated for the average pod number per plant; average grain number per pod, and average grain number per plant; (5) average 100grain mass (from 2 random samples of 100 grain per experimental unit); (6) cycle: number of days from seedling emergence to harvesting, evaluated in all plants from two $5 \mathrm{~m}$-rows of the experimental unit; and (7) these latter plants were submitted to mechanical cleansing to determine grain yield expressed in $\mathrm{kg} \mathrm{ha}^{-1}$ (with $13 \%$ moisture). Data were analyzed separately for each cropping year, since the variances among years were out of the limit variation recommended for satisfactory grouping analysis (Pimentel Gomes, 1985).

\section{RESULTS AND DISCUSSION}

During the three years of field tests, the common bean seedling emergence was uniform, with 13 plants $\mathrm{m}^{-1}$, as expected. Also, for the three experiments, the full flow- 
ering and harvesting occurred approximately at 40 and 90 days after seedling emergence, respectively. No significant interactions were observed among the evaluated variables.

The soil management treatments did not affect plant dy matter yields (Table 1) in any of the three years. These results do not confirm the tendency for higher dry matter yield values previously observed for the no-tillage system (Urchei et al., 2000), but agree with results obtained by Stone \& Moreira (2001), who did not observe any effect of soil tillage on this variable. Concerning effects of nitrogen rates on plant dry matter yields, a significant increase was observed only during the first year, and data fitted a quadratic regression equation (Figure 1). During the two following years, the application of 75 to $100 \mathrm{~kg} \mathrm{ha}^{-1}$ of $\mathrm{N}$ resulted in the highest dry matter yields, corroborating similar positive results obtained by Silveira \& Damasceno (1993), Lima et al. (2001), and Stone \& Moreira (2001). Nevertheless, sometimes the dry matter yields of common beans do not increase in response to application of sidedressed N-rates (Arf et al., 1994).

Higher shoot $\mathrm{N}$ concentration values were observed in plants from the no-tillage treatment in the first year (Table 1), and were within the adequate limit range for common beans according to the literature. Similar results, that is, higher plant $\mathrm{N}$ concentration in the no-till-

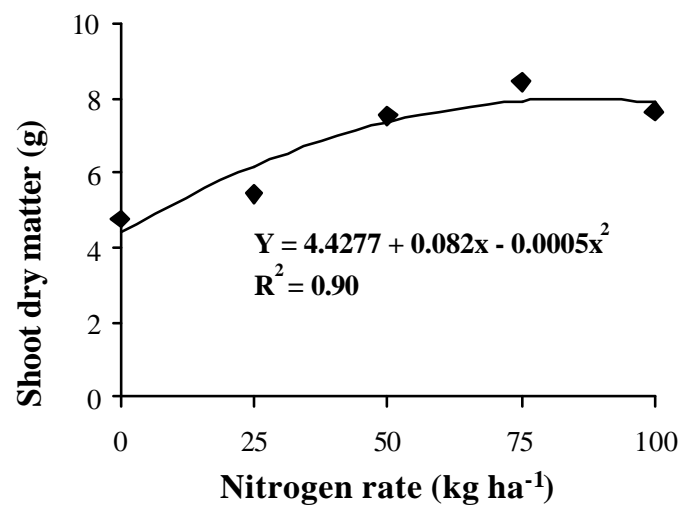

Figure 1 - Variation of shoot dry matter with increasing nitrogen rates. 2000 age system, were also obtained by Silveira \& Damasceno (1993). However, the tillage system may not always affect this variable (Stone \& Moreira, 2001). The N rates resulted in increasing shoot $\mathrm{N}$ concentration in the years 2001 (linear effect) and 2002 (quadratic effect) (Figure 2 ), what might have resulted from higher available $\mathrm{N}$ concentration in the soil. Maximum shoot $\mathrm{N}$ concentration obtained was $39.9 \mathrm{~g} \mathrm{~kg}^{-1}$, and corresponded to soil $\mathrm{N}$ application of $68.4 \mathrm{~kg} \mathrm{ha}^{-1}$. Stone \& Moreira (2001) also observed increasing shoot $\mathrm{N}$ concentrations with increasing $\mathrm{N}$ rates applied to the soil.

Number of pods and grains per plant were not affected by the tillage treatments (Table 2). Such results disagree with those obtained by Stone \& Moreira (2001), who observed lower pod number per plant in the no-tillage treatment. On the other hand, experiments on soil management using several methods (no-tillage, moldboard-plow, and disk harrow) have shown higher pod number per plant in the no-tillage treatment in comparison to the other systems, allowing infer to that the pod number may vary not only with the soil tillage system but also with other yield component factors, such as cropping year and related environmental conditions (Stone \& Moreira, 2000), or else, with the cropping microclimate itself. There were consecutive decreases in both variables along the three cropping years, for all tillage systems used (Table 2).

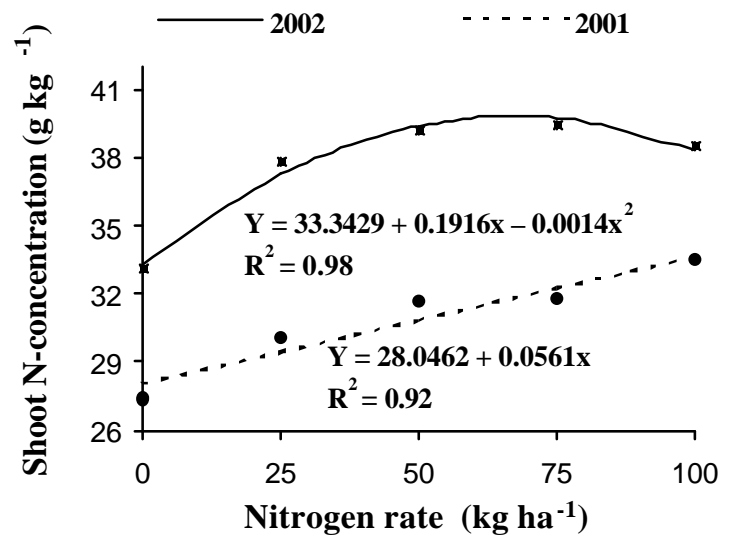

Figure 2 - Variation of shoot nitrogen concentration with increasing nitrogen rates.

Table 1 - Shoot dry matter yields and N-concentrations at flowering of a common bean crop under different soil tillage systems.

\begin{tabular}{|c|c|c|c|c|c|c|}
\hline \multirow{2}{*}{ Soil tillage system } & \multicolumn{3}{|c|}{ Shoot dry matter } & \multicolumn{3}{|c|}{ Shoot $\mathrm{N}$ concentration } \\
\hline & 2000 & 2001 & 2002 & 2000 & 2001 & 2002 \\
\hline & \multicolumn{3}{|c|}{ - } & $-\ldots$ & $\mathrm{g} \mathrm{kg}^{-1}$ & $-\ldots$ \\
\hline No-tillage & 6.84 & 6.85 & 8.05 & $30.63 \mathrm{a}$ & 31.14 & 37.00 \\
\hline Conventional tillage & 7.04 & 6.65 & 7.40 & $27.65 \mathrm{~b}$ & 30.84 & 38.30 \\
\hline Minimal tillage & 6.41 & 7.93 & 8.70 & $27.17 \mathrm{~b}$ & 30.57 & 37.50 \\
\hline C.V. (\%) & 22.45 & 23.94 & 28.21 & 12.83 & 11.43 & 10.73 \\
\hline
\end{tabular}

Means followed by common letters in the columns do not differ by Tukey test $(0.05)$. 
Nitrogen rates increased linearly number of pods seeds number per plant in the years 2000 and 2002 (Figures 3 and 4), evidencing a direct effect of $\mathrm{N}$-fertilization on these variables.

The soil tillage systems did not affect the number of grains per pod in the years 2000 and 2002. Only during 2001, the use of moldboard-plow + leveling disk (Table 3) resulted in higher grain number per pod. These results disagree with those obtained by Stone \& Moreira (2000), who concluded that the no-tillage system provided the highest number of grains per pod, in comparison to the conventional methods. In relation to the $\mathrm{N}$ application, a linear increase in the number of grains per pod with the $\mathrm{N}$ rates was observed only during the year 2001 (Figure 5).

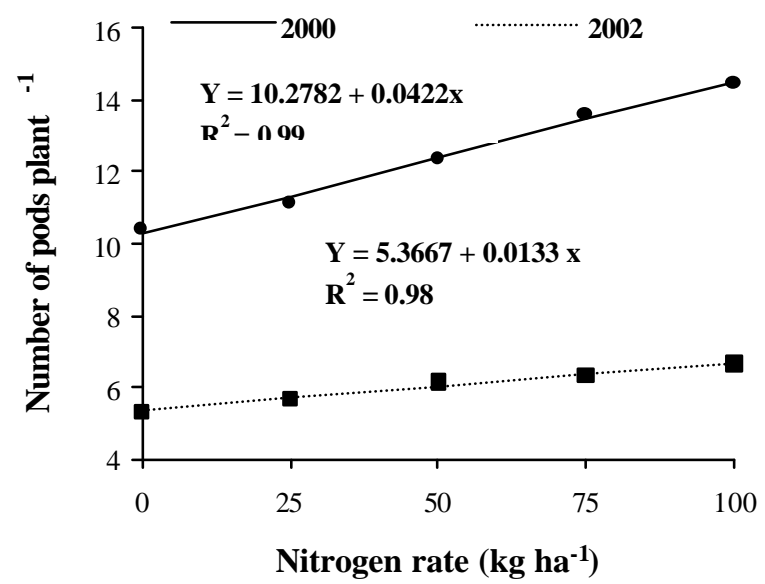

Figure 3 - Variation of the number of pods per plant with increasing nitrogen rates.
The 100-grain mass was higher only in 2001 for the minimal tillage treatment (Table 3). This might be explained by the lower number of pods per plant which occurred in the same year and treatment. The no-tillage was the soil management treatment that provided the lowest values for this variable. As a matter of fact Stone \& Moreira (2001) reported that the no-tillage system might occasionally result in lower 100 -grain mass values. In 2001 and 2002, linear increases in the 100-grain mass values were obtained with increasing $\mathrm{N}$ rates (Figure 6), corroborating results previously observed by Stone \& Moreira (2000) and Arf et al. (1994).

Variation in grain yield with the soil tillage system was only observed during 2001 (Table 4), when the

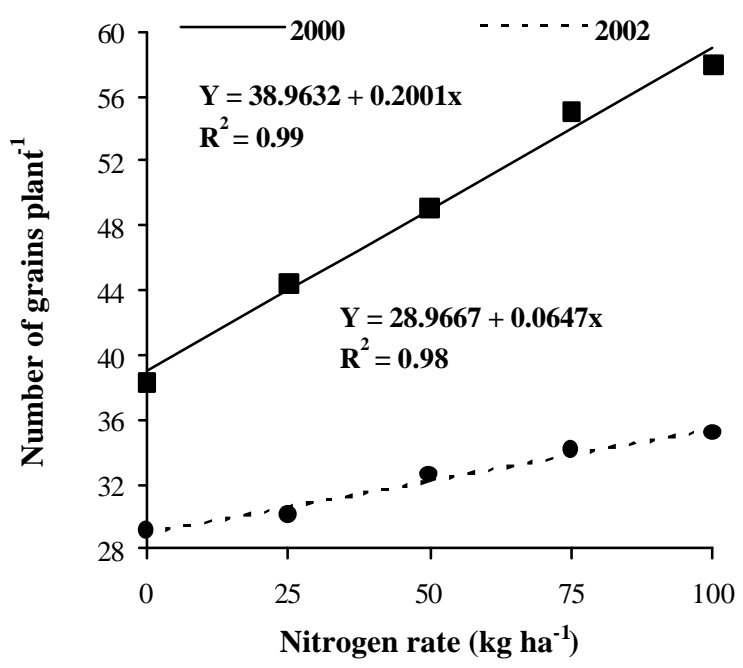

Figure 4 - Variation of the number of grains per plant with increasing nitrogen rates.

Table 2 - Number of pods and grains per plant of a common bean crop under different soil tillage systems.

\begin{tabular}{|c|c|c|c|c|c|c|}
\hline \multirow{2}{*}{ Soil tillage system } & \multicolumn{3}{|c|}{ Number of pods per plant } & \multicolumn{3}{|c|}{ Number of grains per plant } \\
\hline & 2000 & 2001 & 2002 & 2000 & 2001 & 2002 \\
\hline No-tillage & 12.97 & 10.26 & 5.75 & 50.91 & 44.08 & 30.70 \\
\hline Conventional tillage & 11.74 & 10.74 & 5.95 & 46.64 & 45.38 & 32.40 \\
\hline Minimal tillage & 12.46 & 10.03 & 6.40 & 49.36 & 44.89 & 33.50 \\
\hline C.V. $(\%)$ & 17.97 & 15.92 & 26.77 & 20.86 & 17.68 & 26.54 \\
\hline
\end{tabular}

Table 3 - Number of grains per pod and mass of 100 grains of a common bean crop under different soil tillage systems.

\begin{tabular}{lccccccc}
\hline \multirow{2}{*}{ Soil tillage system } & \multicolumn{3}{c}{ Number of grains per pod } & & \multicolumn{3}{c}{ Mass of 100 grains } \\
\cline { 2 - 3 } \cline { 5 - 7 } & 2000 & 2001 & 2002 & & 2000 & 2001 & 2002 \\
\hline No-tillage & 3.92 & $4.29 \mathrm{ab}$ & 5.50 & & 27.61 & $20.41 \mathrm{~b}$ & 20.25 \\
Conventional tillage & 3.98 & $4.23 \mathrm{~b}$ & 4.75 & & 25.60 & $20.64 \mathrm{ab}$ & 20.25 \\
Minimal tillage & 3.97 & $4.48 \mathrm{a}$ & 4.25 & & 26.86 & $21.22 \mathrm{a}$ & 20.65 \\
\hline C.V. $(\%)$ & 10.37 & 4.35 & 21.49 & & 13.60 & 4.41 & 5.64
\end{tabular}

Means followed by common letters in the columns do not differ by Tukey test $(0.05)$.

Sci. Agric. (Piracicaba, Braz.), v.61, n.3, p.307-312, May/June 2004 
highest grain yields were observed for the minimal tillage, in agreement with the results reported by Castro et al. (1986), who observed the superiority of the moldboard-plow method of soil tillage in comparison to the conventional methods for common bean yielding. However, during 2000 and 2002, no differences among the soil tillage systems were observed for the bean grain yield, which averaged $2,000 \mathrm{~kg} \mathrm{ha}^{-1}$.

Nevertheless, it is important to point out that the no-tillage system may provide higher bean grain yields than the conventional systems in areas where the presence of straw on soil surface is important to maintain adequate soil moisture and minimize soil temperature fluctuations, favoring retention of $\mathrm{N}$ in the soil (Silveira et al., 1999; Carvalho et al., 1999; Stone \& Moreira, 2000). This was not observed in the present experiment, since rainy summer and high temperatures characterize the region. This condition accelerates straw decomposition and exposes the soil to weathering.

Despite the linear effect of $\mathrm{N}$ rates on grain yield being only noticed in the second year (Figure 7), the application of 75 to $100 \mathrm{~kg} \mathrm{~N}^{-1}$ provided considerable increases in grain yield in the three years. In the second year, the higher number of grains per pod and higher 100seed mass values obtained in response to $\mathrm{N}$-rates were probably the yield components responsible for the increased productivity.

Application of $\mathrm{N}$ actually provides grain yield gains for the common bean crop as reported by Miyasaka et al., 1963; 1966; Mascarenhas et al., 1967; Urben Filho et al., 1980; Arf et al., 1992; Silveira \& Damasceno, 1993; Araújo et al., 1994; Ambrosano et al., 1996; Calheiros et al., 1996; Barbosa Filho \& Silva, 2000; Guerra et al., 2000; Carvalho et al., 2001 and Stone \& Moreira, 2001. The grain yield data obtained in the year 2001 fitted a linear equation: $y=1552,2+2,9 x$. The correspondent $\mathrm{N}$ rate necessary to reach the highest grain yield obtained in the minimal tillage in the same year $\left(1,796 \mathrm{~kg} \mathrm{ha}^{-1}\right)$ was calculated to be $85 \mathrm{~kg} \mathrm{ha}^{-1}$.

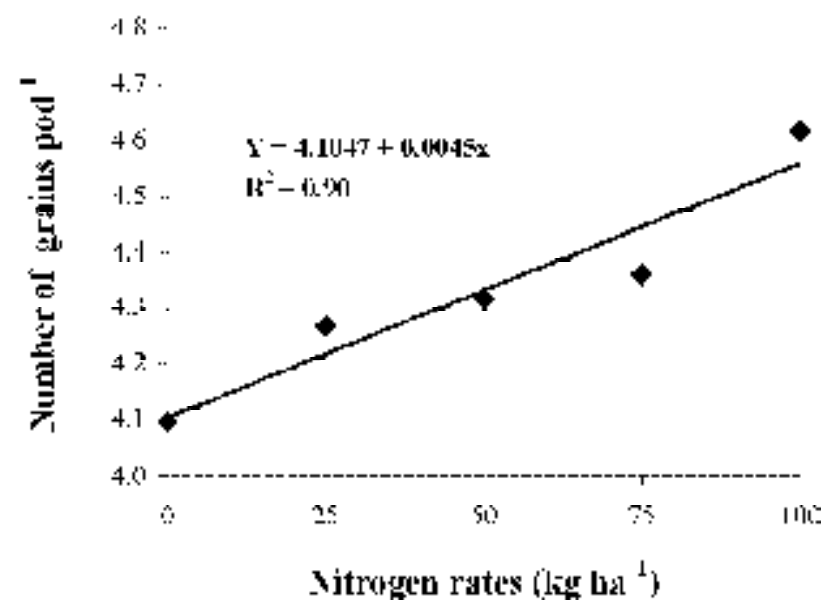

Figure 5 - Variation of the number of grains per pod with increasing nitrogen rates. 2001.

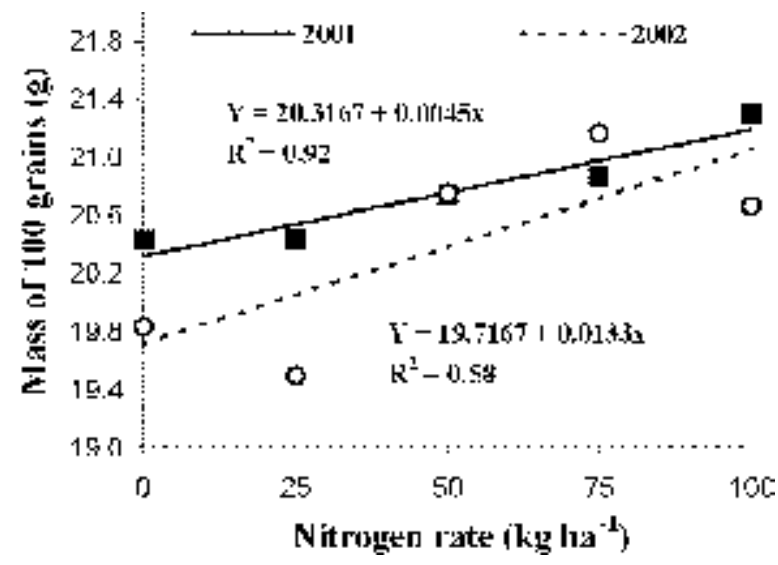

Figure 6 - Variation of mass of 100 grains with increasing nitrogen rates.

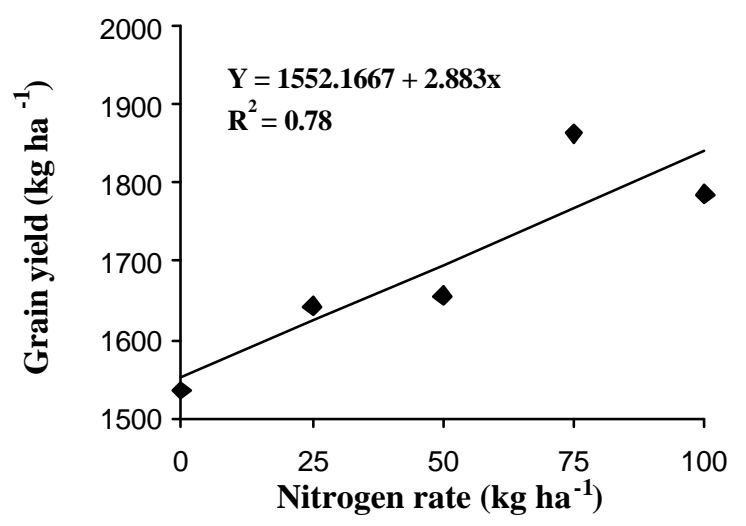

Figure / - Grain y1eld increase with the increasing nitrogen rates, 2001.

Table 4 - Grain yielding of a common bean crop under different soil tillage systems.

\begin{tabular}{|c|c|c|c|c|}
\hline \multirow{2}{*}{ Soil tillage system } & \multicolumn{4}{|c|}{ Grain yield } \\
\hline & 2000 & 2001 & 2002 & Means \\
\hline & \multicolumn{4}{|c|}{ - kg ha ${ }^{-1}$} \\
\hline No-tillage & 1999 & $1575 \mathrm{~b}$ & 2342 & 1972 \\
\hline Conventional tillage & 1943 & $1718 \mathrm{ab}$ & 2590 & 2084 \\
\hline Minimal tillage & 2034 & $1796 \mathrm{a}$ & 2540 & 2123 \\
\hline C.V. $(\%)$ & 20.62 & 10.96 & 22.14 & - \\
\hline
\end{tabular}

Means followed by common letters in the columns do not differ by Tukey test (0.05).

\section{ACKNOWLEDGEMENTS}

The authors acknowledge the Grant (IC) conferred to this research project by "Fundação de Amparo à Pesquisa do Estado de São Paulo (FAPESP)".

\section{REFERENCES}

AMBROSANO, E.J.; WUTKE, E.B.; BULISANI, E.A.; CANTARELLA, H. Feijão. In: RAIJ, B. van; CANTARELA, H.; QUAGGIO, J.A.; FURLANI, A.M.C. Recomendações de adubação e calagem para o Estado de São Paulo. 2.ed. Campinas: IAC, 1996. p.194-195. (Boletim Técnico, 100). 
ARAÚJO, G.A.A.; VIEIRA, C.; MOSQUIM, P.R.; CASSINI, S.T.A. Efeito da época de aplicação do adubo nitrogenado em cobertura sobre o rendimento do feijão, no período de outono-inverno. Revista Ceres, v.41, p.442-450, 1994.

ARF, O.; FERNANDES, F.M.; JACOMINO, A.P.; BUZETTI, S. Comparação de fontes e doses de adubos nitrogenados na cultura do feijoeiro Phaseolus vulgaris L.), cultivado no sistema de "plantio direto". Cultura Agronômica, v.1, p.21-30, 1992.

ARF, O.; SÁ, M.E.; BUZETTI, S.; GUERREIRO NETO, G.; GUTIERREZ, J.A. Inoculação, adubação nitrogenada e micronutrientes como incrementos de produção de feijoeiro (Phaseolus vulgaris L.) na região de Selvíria-MS: Produção de sementes. Cultura Agronômica, v.3, p.151-166, 1994.

BARBOSA FILHO, M.P.; SILVA, O.F. Adubação e calagem para o feijoeiro irrigado na região dos cerrados. Pesquisa Agropecuária Brasileira, v.35, p.1317-1324, 2000.

CALHEIROS, C.M.B.; QUEIROZ, J.E.; FRIZZONE, J.A.; PESSOA, P.C.S. Estratégias ótimas de irrigação do feijoeiro: água como fator limitante de produção.Pesquisa Agropecuária Brasileira, v.31, p.509-515, 1996.

CARVALHO, M.A.C.; ATHAYDE, M.L.F.; ARF, O.; SÁ, M.E. Cultura do feijoeiro de "inverno" em sucessão a milho, soja e algodão, em semeadura direta e convencional com adubação verde. In: REUNIÃO NACIONAL DE PESQUISA DE FEIJÃO, 6., Salvador, 1999. Anais. Goiânia: Embrapa Arroz e Feijão, 1999. v.1, p.642-645.

CARVALHO, M.A.C.; ARF, O.; SÁ, M.E.; BUZETTI, S.; SANTOS, N.C.B.; BASSAN, D.A.Z. Produtividade e qualidade de sementes de feijoeiro (Phaseolus vulgaris L.) sob influência de parcelamentos e fontes de nitrogênio. Revista Brasileira de Ciência do Solo, v.25, p.617-624, 2001.

CASTRO, O.M.; NETO LOMBARDI, F.; VIEIRA, S.R.; DECHEN, S.C.F. Sistemas convencionais e reduzidos de preparo do solo e as perdas por erosão. Revista Brasileira de Ciência do Solo, v.10, p.167-171, 1986.

COELHO, F.C.; VIEIRA, C.; MOSQUIM, P.R.; CASSINI, S.T.A. Nitrogênio e molibdênio nas culturas do milho e do feijão em monocultivos e em consórcios: efeitos sobre o feijão. Revista Ceres, v.45, p. 393-407, 1998.

GOMES,F.P. Curso de estatística experimental. São Paulo: ESALQ, 1985. $467 \mathrm{p}$.

GUERRA, A.F.; SILVA, D.B.; RODRIGUES, G.C. Manejo de irrigação e fertilização nitrogenada para o feijoeiro na região dos cerrados. Pesquisa Agropecuária Brasileira, v.35, p.1229-1236, 2000.

INSTITUTO AGRONÔMICO DE CAMPINAS. IAC Carioca Eté, novo feijoeiro de alta produtividade. O Agronômico, v.51, p.35-36, 1999.

KLUTHCOUSKI, J.; BOUZINAC, S.; SEGUY, L. Preparo do solo. In: ZIMMERMANN, M.J.O. Cultura do feijoeiro: fatores que afetam a produtividade. Piracicaba: Potafós, 1988. p.249-259.

LANDERS, J.N. Fascículo de experiências de plantio direto no cerrado. Goiânia: APDC, 1995. 261p.

LIMA, E.V.; ARAGÃO, C.A.; MORAIS, O.M.; TANAKA, R.; GRASSI FILHO, H. Adubação NK no desenvolvimento e na concentração de macronutrientes no florescimento do feijoeiro. Scientia Agricola, v.58, p.125-129, 2001.

MASCARENHAS, H.A.A.; MIYASAKA, S.; IGUE, T.; LOVADINI, L.A.; FREIRE, E.S. Adubação mineral do feijoeiro XI - Efeitos de N, P, K e da calagem em Campos Cerrados do Planalto Paulista. Bragantia, v.26, p.303-316, 1967.

MIYASAKA, S.; FREIRE, E.S.; MASCARENHAS, H.A.A. Modo e época de aplicação de nitrogênio na cultura do feijoeiro. Bragantia, v.22, p.511$519,1963$.

MIYASAKA, S.; FREIRE, E.S.; MASCARENHAS, H.A.A.; PETTINELLI, A.; IGUE, T. VIII - Efeitos de N, P, K, S e de uma mistura de micronutrientes, em novas experiências conduzidas em Tatuí e Tietê. Bragantia, v.25, p.393-406, 1966.

MORAES, J.F.V. Calagem e adubação. In: ZIMMERMANN, M.J.O.; ROCHA, M.; YAMADA, T. (Ed.) Cultura do feijão: fatores que afetam a produtividade. Piracicaba: Potafós, 1988. p.261-302.
RAIJ, B. van; QUAGGIO, J.A. Métodos de análise de solo para fins de fertilidade. Campinas: Instituto Agronômico, 1983. 31p. (Boletim Técnico, 81).

RAIJ, B. van; CANTARELLA, H. Milho para grão e silagem. In: RAIJ, B. van; CANTARELlA, H.; QUAGGIO, J.A.; FURLANI, A.M.C. Recomendações de adubação e calagem para o Estado de São Paulo 2.ed. Campinas: IAC, 1996. p.56-58. (Boletim Técnico, 100).

SAMPAIO, G.V.; GALVÃO, J.D.; FONTES, L.A.N.; FIGUEIREDO, M. de S.; CARDOSO, A.A. Efeitos de sistemas de preparo do solo sobre o consórcio milho-feijão (Phaseolus vulgaris L.) Revista Ceres, v.36, p.465-482, 1989.

SARRUGE, J.R.; HAGG, H.P. Análises químicas em plantas. Piracicaba: ESALQ, Depto. Química, s.n. 1974. 54p.

SILVA, V.A.; ANDRADE, M.J.B.; RAMALHO, M.A.P. Efeitos de métodos de preparo do solo e níveis de fertilizante NPK sobre o feijão da "seca" (Phaseolus vulgaris L.) em sequiência à cultura do milho. In: REUNIÃO NACIONAL DE PESQUISA DE FEIJÃO, 5., Goiânia, 1996. Anais. Goiânia: EMBRAPA, CNPAF, 1996. v.1, p.418-420. (Documentos, 69).

SILVEIRA, P.M.; DAMASCENO, M.A. Doses e parcelamento de K e de N na cultura do feijoeiro irrigado. Pesquisa Agropecuária Brasileira, v.28, p.1269-1276, 1993.

SILVEIRA, P.M.; SILVA, S.C.; ZIMMERMANN, F.J.P.; CUNHA, A.A. Amostragem e variabilidade espacial da produtividade do feijoeiro em uma área experimental submetida a diferentes sistemas de preparo do solo. In: REUNIÃO NACIONAL DE PESQUISA DE FEIJÃO, 6 , Salvador, 1999. Anais. Goiânia: Embrapa Arroz e Feijão, 1999. p.613616.

SILVEIRA, P.M.; SILVA, O.F.; STONE, L.F.; SILVA, J.G. Efeito do preparo do solo, plantio direto e de rotações de culturas sobre o rendimento e a economicidade do feijoeiro irrigado. Pesquisa Agropecuária Brasileira, v.36, p.257-263, 2001

SIQUEIRA, R.; YAMAOKA, R.S.; CASÃO JR., R. Sistemas de preparo e coberturas vegetais em um solo de baixa aptidão agrícola. In ENCONTRO LATINO AMERICANO SOBRE PLANTIO DIRETO NA PEQUENA PROPRIEDADE, 1., Ponta Grossa, 1993. Anais. Ponta Grossa: IAPAR, 1993. p.221-237.

STONE, L.F.; SILVEIRA, P.M. Efeitos do sistema de preparo na compactação do solo, disponibilidade hídrica e comportamento do feijoeiro. Pesquisa Agropecuária Brasileira, v.34, p.83-91, 1999.

STONE, L.F.; MOREIRA, J.A.A. Efeitos de sistemas de preparo do solo no uso da água e na produtividade do feijoeiro.Pesquisa Agropecuária Brasileira, v.35, p.835-841, 2000.

STONE, L.F.; MOREIRA, J.A.A. Resposta do feijoeiro ao nitrogênio em cobertura, sob diferentes lâminas de irrigação e preparos do solo. Pesquisa Agropecuária Brasileira, v.36, p.473-481, 2001.

UNITED STATES DEPARTMENT OF AGRICULTURE - USDA. Keys to soil taxonomy. 7.ed. Washington: USDA, 1996.644p.

URBEN FILHO, G.; CARDOSO, A.A.; VIEIRA, C.; FONTES, L.A.N.; THIÉBAUT, J.T.L. Doses e modos de aplicação do adubo nitrogenado na cultura do feijão. Revista Ceres, v.27, p.302-312, 1980.

URCHEI, M.A.; RODRIGUES, J.D.; STONE, L.F. Análise de crescimento de duas cultivares de feijoeiro sob irrigação, em plantio direto e preparo convencional. Pesquisa Agropecuária Brasileira, v.35, p.497-506, 2000

ZAFFARONI, E.; BARROS, H.H.A.; LÓBREGA, J.A.M.; LACERDA, J.T.; SOUZA JR., V.E. de. Efeito de métodos de preparo do solo na produtividade e outras características agronômicas de milho e feijão no Nordeste do Brasil. Revista Brasileira de Ciência do Solo, v.15, p.99104, 1991.

Received June 12, 2003

Accepted March 09, 2004 